\title{
Deliberative, Republican, and Egalitarian Institutional Alternatives for Popular Constitutionalism**
}

\author{
Alternativas deliberativas, \\ republicanas e igualitarias para \\ el constitucionalismo popular
}

\begin{abstract}
This article examines and proposes institutional instantiations for popular constitutionalism. The proposal is a progressive combination of institutions aiming at giving the citizenry the opportunity to determine what a constitution means, contributing to securing their liberty in a republican sense, implementing mechanisms of deliberation, and being respectful to a particular understanding of political equality. It first describes popular constitutionalism and the principles I believe should ground it. It then moves on to scrutinise sundry institutional alternatives available in the literature. After showing the areas where those proposals fall short of instantiating the principles here championed, the article argues for the implementation of four mechanisms that, I argue, do incarnate those principles.
\end{abstract}

KEYWORDS

Popular constitutionalism, republicanisms, institutional design, deliberation, political equality.

* $\quad$ LLB (Universidad Austral de Chile); MA in Advanced Studies of Philosophy (Universidad de Valladolid); Doctor of Philosophy (Universities of Valladolid and Salamanca), Ph. D. in Political Theory (King's College London). Flanders Research Foundation (Fwo) Postdoctoral Fellow, KU Leuven; e-mail: donaldemerson.bellohutt@kuleuven.be. orcID: 0000-0003-2979-6631.

The author wishes to thank two reviewers of this journal. My personal thanks also go to José Luís Martí, Ignacio Giuffré, Dimitrios Kyritsis, Jeff King, and Iseult Honohan for their comments to earlier versions of this article. The manuscript was presented at the García Pelayo Seminar (Centro de Estudios Políticos y Constitucionales, Madrid) and at the IVR Special Workshop on "Alternatives to Liberal Constitutionalism" in Lucerne (2019). My thanks to Ana Belén Benito and Ana Cannilla for the possibility of presenting in those events.

** Recibido el 9 de junio del 2020, aprobado el 31 de agosto del 2020.

Para citar el artículo: Deliberative, Republican, and Egalitarian Institutional Alternatives for Popular Constitutionalism. En Revista Derecho del Estado, Universidad Externado de Colombia. N. ${ }^{\text {}} 48$, enero-abril de $2021,183-214$.

DOI: https://doi.org/10.18601/01229893.n48.07 
RESUMEN

Este artículo examina y propone alternativas institucionales para el constitucionalismo popular. La propuesta es una combinación progresiva de instituciones que buscan dotar a la ciudadanía con el poder final para determinar qué significa una constitución, contribuyendo a asegurar su libertad republicana, implementando mecanismos de deliberación, al tiempo que es respetuoso de una forma particular de comprender la igualdad política. El artículo comienza con una descripción del constitucionalismo popular y de los principios que considero que deberían fundamentar la teoría. Luego, procede a examinar críticamente diversas propuestas institucionales presentes en la literatura. Después de mostrar las áreas en las que dichas propuestas se quedan cortas en el esfuerzo de encarnar los principios aquí defendidos, el artículo aboga por la implementación de cuatro mecanismos que, según sostendré, sí se acercan más a dichos objetivos.

PALABRAS CLAVE

Constitucionalismo popular, republicanismo, diseño institucional, deliberación, equidad política.

\section{SUMMARY}

Introduction. I. Popular constitutionalism: definition and principles. II. Alternatives available in the literature. A. Kramer's proposal. B. Donnelly's "people's veto". C. Pozen's "judicial elections". III. Republican, deliberative, and egalitarian proposals for popular constitutionalism. A. Commonwealth models' institutions. B. Parliamentary deliberation and justification. C. Constitutional mini-publics. 1. Selection methods. 2. Procedure. 3. And back to transmission. Iv. Conclusions. References

\section{INTRODUCTION}

This article examines and proposes institutional instantiations for popular constitutionalism. The proposal is a progressive combination of institutions aiming at giving the citizenry the opportunity to determine what a constitution means, contributing to securing their liberty in a republican sense, implementing mechanisms of deliberation, and being respectful to a particular understanding of political equality.

The paper proceeds as follows: section I describes popular constitutionalism and the principles grounding my own understanding of the theory. By relying on work undertaken elsewhere, I argue that giving the final word in constitutional interpretation to citizens requires a republican, deliberative, and egalitarian combination of institutional conditions and mechanisms. 
Section II examines institutional alternatives available in the literature meant to implement popular constitutionalism. I do this to justify why additional measures are required. I discuss proposals by Kramer, Donnelly, and Pozen, as they are some of the most articulated ones available in the literature. These proposals fall short of achieving popular constitutionalism's goal of giving the final word in constitutional interpretation to the people themselves.

Section III elaborates my own proposals. It argues for the implementation of the following mechanisms compatible with the republican, deliberative and egalitarian principles I champion: contestation without erga omnes effects, commonwealth-constitutionalism's judicial review, parliamentary deliberation and justification, and interpretive constitutional mini-publics. They are presented and defended in a progressive manner; moving from mechanisms already available in most contemporary polities to democratic innovations whose employment is less frequent, but which are nevertheless well grounded in social theory.

The proposals are conditioned in different ways. First, they do not exhaust the range of solutions necessary to realise the principles summarised in section I. The magnitude and reach of those desiderata overflow any concrete institutional arrangement one could propose. Institutional design must aim at realising principles to the greatest possible extent. One must be aware, however, that those arrangement will likely run short of reaching the objectives set by their guiding principles. This is not a limitation as such, but how regulative ideals operate.

There is also an issue of domain. Should popular constitutionalists focus on realising the theory`s principles outside representative institutions? Or should they aim at improving representative government? This is, I think, a false dilemma whose resolution hinges on the notion of representation one endorses. As I make clear below, I endorse a notion of representation that does not disconnect representatives from the discursive preferences of those they represent. Representative institutions, in such a model, do not exist simply by virtue of practical necessities like scale and time. They are a necessary component of the justification of our collective societal decisions. The question is, then, not so much do we need representatives, but how do we facilitate discursive transmissions from the public sphere to representative institutions.

These considerations do not treat discussions on the justification of representative government as irrelevant. But the topic is complex enough as to merit an examination I cannot fully provide here. I thus take sides with one specific understanding of representation because it allows me to interpret the relationship between ordinary citizens and representative formal institutions as a continuum rather than as a solution for practicalities of scale. This is compatible with and accounts for the features of popular constitutionalism I advocate for: popular constitutionalism coexists with representative institutions. 
My endorsement of republicanism, deliberative democracy, and political equality implies that the people themselves are entitled to discuss, and capable of discussing, the merits, justice, fairness, defects, etc., of the available alternatives in a decision-making process, not just about the effects the chosen alternatives will have on themselves, but also on the rest of the members of the polity they are part of. This is, admittedly, a lot to ask from a single institutional recommendation.

This entails a difficulty with regard to the pre-conditions under which an institution is supposed to operate, as it would make little sense to incorporate institutional devices that put the people themselves to deliberate in polities where no basic rights and basic material conditions are guaranteed. It is indeed wishful thinking to expect that people deprived of such conditions will be in fact capable and willing to discuss complex collective affairs. These conditions are demanded by the material dimension of EAD. The success of the institutional proposals I here make depend on an initial realisation of that principle, notwithstanding they also materialise and strengthen it. The capacity of the public within the deliberative process thus depends on its "support of a societal basis in which equal rights of citizenship have become socially effective". ${ }^{1}$ Just how exactly these preconditions would be implemented and/ or satisfied is beyond the scope of this paper.

Section IV concludes.

\section{POPULAR CONSTITUTIONALISM: DEFINITION AND PRINCIPLES}

This section presents the normative principles guiding my understanding of popular constitutionalism. It serves two purposes. First, these principles serve as standards of criticism for the alternatives available in the literature. Second, they operate as regulative ideals for my own proposals.

A brief sketch of popular constitutionalism is called for. Popular constitutionalism is a theory mostly developed in the United States, ${ }^{2}$ whose most general claim is that it should be the people themselves the ones who should have the final word in constitutional interpretation. The expression the people themselves, taken from Madison, ${ }^{3}$ means that citizens have the right to be final authorities in ascribing meaning to their constitution. ${ }^{4}$ This broad definition encompasses two theses. First, the descriptive thesis that traditionally, and increasingly, the task of giving authoritative and final interpretations to the

1 Habermas $(1996,308)$.

2 There are noteworthy exceptions outside the US as well. See Alterio \& NiEMbro Ortega (2013); Gargarella (2013); Rodríguez Garavito (2013); Linares (2013); Tushnet (2013); Hogg \& Bushell (2013); LoRENZETTI (2013).

3 Madison (2006).

4 For example, Levinson (2000); Balkin (2003); Kramer (2007). 
constitution is given to the judiciary. ${ }^{5}$ Second, the normative contention that this power could and should belong to a different agent. Authors generally understand the people themselves to be actual citizens, persons who should be given the chance to have a say and steer the ongoing process of giving meaning to the constitution. ${ }^{6}$

After a period of strong scholarly interest raised by the publication of Larry Kramer's The People Themselves, ${ }^{7}$ the theory experienced a decline. ${ }^{8}$ One of the main reasons explaining this decay is, I submit, a lack of convergence on principles grounding the claims popular constitutionalists generally endorse. This normative feebleness has led popular constitutionalists, for example, to debate whether the Tea Party constitutes an example of popular constitutionalism, which poses a challenge to those equating the theory with a progressive reading of the constitution ${ }^{10}$. Moreover, some commentators have pointed to linkages between popular constitutionalism and originalism. Both categories are, however, prima facie incompatible due to the originalist commitment to the preserve the dead hand of the past as a criterion to interpret the constitution. ${ }^{11}$

The theory thus needs further development. The differences on the nature of the claims that seem to fall into the label popular constitutionalism are too many as to accept it as a guidance, let alone endorse it, in its current state. This section offers an alternative for filling this gap.

I have elaborated the principles I advocate for elsewhere (Bello Hutt 2018). Yet, in a nutshell, my take is the following: popular constitutionalism must secure and foster republican liberty and deliberation among citizens, against a background of egalitarian conditions demanded by a principle of political equality I call Equality of Access and Deliberation (EAD). I will not expound these concepts in full detail here, but it is important to sketch them for the sake of the present argument.

5 Also, see, Dworkin (1992, 383); Ackerman (1997); Shapiro \& Stone Sweet (2002); Tushnet (2003, 453); Hirschl (2004); Gargarella (2006, 15); Alexander \& Solum (2005, 1597); Kramer (2007, 697); Ginsburg (2008); Donnelly (2009, 958); Niembro (2013, 195); McConnell $(2015,1783)$; MaC AMHLaigh $(2016,175-176)$.

6 Tushnet $(1999$, x , 108); Kramer $(2004,959,973,980)$; Kramer $(2005,1344)$; DonNELLY $(2009,957)$.

7 As affirmed by a commentator, Kramer's book struck a nerve. It was reviewed in almost every major law review, and in most newspapers in the United States: "The People Themselves has generated intense discussion concerning the rise of judicial power in the United States and the role of popular politics in retraining, or failing to restrain, that power of the course of American history" (D. W. Hamilton 2006, 809). To name a few publications commenting on The People Themselves: Chemerinsky, 2004; Post \& Siegel 2004; Carney 2005, 493; Braveman 2005.

8 See, for example, Knowles \& Toia, claiming that "there is reason to believe that "popular constitutionalism, as it is used by academic writing in law journals, is no longer a meaningful concept" $(2014,34)$.

9 E.g., SсHмiDT $(2011,7)$.

10 Schwartzberg (2011); Post \& Siegel $(2009,31)$.

11 Zietlow $(2012,485-486)$. 
Republicanism is constituted by two main principles, namely, liberty as non-domination and civic virtue. Other principles may be part of the republican ideal, but these two are at the core of any republican account.

The most characteristic feature of republicanism is its conception of freedom as non-domination or as a structural independence upon the will of another. ${ }^{12}$ In a republican framework, freedom "is restricted not merely by actual interferences or the threat of, but also by our awareness of the mere fact that we are living in dependence on the good goodwill of others". ${ }^{13}$ Thus conceived, freedom is defined a status in virtue of which an agent is not subjected to the domination of an individual or a group. In turn, individuals have dominating power over others to the extent that they have a capacity to interfere with the dominated agent, that this interference is brought about on an arbitrary basis, and that is made regarding certain choices that the dominated agent is in a position to make. ${ }^{14}$

In turn, deliberative democracy is a theory whose core claims are that collective decisions should be adopted via a method of deliberation, with the inclusion of all potentially affected by the decisions. ${ }^{15}$ Accordingly, deliberation operates as a justification as well as a condition for the legitimacy of the decisions adopted. ${ }^{16}$ Additionally, it has the nature of a regulative ideal - a horizon decision-making processes should strive to attain. ${ }^{17}$ This explains, for example, the ideal character of Cohen's deliberative procedure, ${ }^{18}$ and Habermas' unlimited community of communication. ${ }^{19}$

There are valuable instrumental linkages between republican freedom and civic virtue pointing at deliberative democracy as the best institutional means to prevent domination. This is because being free in a republican sense entails that individuals participate in the process by which they give norms to themselves, to the greatest extent possible. Moreover, it requires the preferences and arguments manifested in the decision-making process to be the highest possible expression of autonomous reasoning and not of preferences imposed by others. These are conditions that deliberative democracy is meant to implement.

Deliberative democrats consider that political participation is achieved when every potentially affected person by an eventual decision is present as a discussant. This provides distinctiveness to its ideal of participation,

12 For definitions of republican liberty, see Sydney (1698, p. 17), Pettit (1997, pp. 51-79; 2002, pp. 339-342; 2012, pp. 7-8, 26-74), SKINNER (1998, p. 70; 2002, p. 247; 2008, p. x), LARMORE (2001, pp. 229-230), McCormick (2011, p. 145) and LovetT (2014).

13 SKInNER (2002, p. 247).

14 Pettit $(1997,52)$.

15 ELSTER $(1998,8)$.

16 Manin $(1987,359)$; Gutmann \& Thompson (1996, 4); Bohman $(1996,4)$; Bohman (1998, 401, 402); Bohman $(2009,28)$; Chambers $(2003,308)$; Martí $(2006,22)$.

17 Kant (1996: A569-B597); Martí (2006, 25); MANSBRidge et al. $(2010,65)$.

18 COHEN $(1998,67,72-9)$.

19 Habermas $(1993,56)$. 
compared to other political theories, a difference well portrayed by Elster's metaphor: in a deliberative democracy, democratic participation is modelled on a forum, not in a market. Inclusion is instrumental to the republican cause by guaranteeing the right to be present in a substantive way, to the extent that individuals are affected by the potential decision adopted.

Deliberative democracy also puts into place the conditions for individuals to express their preferences, hear the preferences of others, weigh them, form, transform them, and justify them in a context of relative equality, so that no individual is able to arbitrarily impose her own view to others.

Reading these two theories as compatible to each other entail the endorsement of EAD. The relation of EAD with deliberative democracy and republicanism, is intrinsic, meaning that eliminating or reducing the domination of some agents over others is linked to the guarantee of the equal possibility of having a say, justifying one's preferences and considering those of others.

EAD comprises two principles: equality of access and equality in deliberation. First, equality of access means that all potentially affected by collective decisions must have the equal opportunity of entering the fora where those decisions are adopted. Second, equality in deliberation requires that decision-making processes be sensitive enough as to be able to capture, make visible, and consider the claims of all the participants in the debate in non-dominating manners.

Taken together, these principles give substance to the main theses endorsed by popular constitutionalists - giving the citizenry the final word in the interpretation of a constitution is conducive to enhancing their freedom as non-domination, to the extent that the process by citizens impose meaning to their constitution allows all those potentially affected persons the possibility to discuss and decide on the best available meaning. Such process must include egalitarian safeguards for the inclusion, and for non-dominating deliberation within the deliberative decision-making forum.

\section{ALTERNATIVES AVAILABLE IN THE LITERATURE}

I now examine institutional proposals made by four popular constitutionalists: Kramer, Donnelly, and Pozen, I show that, to different degrees and for different reasons, they fail to meet the republican and deliberative conditions described above.

\section{A. Kramer's proposal}

Kramer's positive contributions to popular constitutionalism are rather limited:20

20 Additional limitations of Kramer's account are discussed in Beaumont (2014). I share those critiques. However, because they are limited to the United States Constitutional history and practice, I will not discuss them here. 
[j]ustices can be impeached, the [Supreme] Court's budget can be slashed, the President can ignore its mandates, Congress can strip it of jurisdiction or shrink its size or pack it with new members or give it burdensome new responsibilities or revise its procedures. ${ }^{21}$

Not all of these measures advance the popular constitutionalists' agenda. It is hard to see why and how impeachment, budget cuts, changes in the court's size or increasing administrative or bureaucratic burdens on judges would realise the principle that the people themselves should be final constitutional interpreters. They would hinder the exercise of judicial prerogatives but would leave the central issue untouched, as neither of them involve modifying the courts' competences and attributions. Courts burdened with these measures may still retain the final word. The only difference perhaps, would be noticed in the quality of their judgements or in the time it may take the court to issue them.

Revising the courts' procedures and competences, on the other hand, aims in the right direction. Procedures condition competences, and to the extent that courts are constrained procedurally as final authorities, their political power is likely to be transferred to other agents. Yet, Kramer just mentions these measures without elaborating on how they would work in practice. Instead, Kramer provided a "framework in which to think about such matters", ${ }^{22}$ based on what he calls "Madison's theory of deliberative democracy", ${ }^{23}$ namely, a departamentalist account of the inner workings of the principle of separation of powers, more than an actual deliberative model.

This model is weak from a republican and a deliberative standpoint. $\mathrm{He}$ calls deliberativist a model that is closer to one whose aim is "to aggregate individual preferences into a collective choice in as fair and efficient a way as possible" 24 . The departamentalism he endorses seeks to guarantee the community's control over the interpretation of constitutional law achieved through a system amounting "to a competition of understandings among political officials that, by forcing the leadership class to appeal to the community for support, would simultaneously inform public opinion and secure its sovereignty". ${ }^{25}$ But this is more Schumpeterian than deliberative. No further reflections are offered on how each branch would come up with its own position on constitutional matters, nor on the ways public opinion could be influenced, included, how it would deliberate, and what its role would be within a system of deliberation other than being a reference point to which public authorities ought to direct their attention.

\footnotetext{
21 Kramer $(2004 a, 249)$.

22 Kramer $(2007,702)$.

23 KRAMER $(2007,748)$.

24 Miller $(1992,55)$.

25 Kramer $(2007,749)$.
} 
Kramer's model is also problematic from a republican standpoint, particularly with regard to the notion of control. In his wording, popular constitutionalism's basic idea is "that final authority to control the interpretation and implementation of constitutional law resides at all times in the community in an active sense" and that "there are countless institutional arrangements by which popular control can become meaningful" ${ }^{26}$ Control is central in republican democratic accounts. In Pettit's account, to have a degree of control over a result, two things are essential:

First, you must have some influence over the process leading to the result. And second, you must use that influence to impose a relevant direction on the process, helping to ensure that a suitable result transpires. ${ }^{27}$

The influence must in turn give rise to a recognisable pattern, and that pattern must be one the subject seeks. ${ }^{28}$ Hence, there is no control "without an influencebearing input that controls for the realisation of a suitably patterned output". ${ }^{29}$ There must be a system of popular influence over government that is "equally accessible to each and pushes government in a direction [...] determined, directly or indirectly, by considerations that all can treat as relevant to public decision-making". ${ }^{30}$ To the extent these conditions obtain, it follows that subjects are not under the arbitrary will of others, that is, they are not dominated. Note that the condition for liberty is not that subjects can do whatever they want without interference. It means, rather that interferences are legitimate if they are not arbitrary ( (Bello Hutt 2017a).

Kramer neither says how individuals would be safe from being dominated by state agents nor how individuals could retain final control and thus be safe from, in this case, vertical domination by public authorities. Because his focus is on institutional dialogue and not on how the broader public sphere could permeate formal institutions, state organs could still manipulate the decision-making process. Surprisingly, as his reflections become more concrete, the more they envision a top-down relationship of state organs with the public: departmentalism, in his view, is a process "for channelling different positions to the public through functional agencies". ${ }^{31}$

So the question is how can we keep this functional agencies controlled? In the context of a different debate Kramer argues that "once public sentiment has begun to swing decisively in a particular direction, the political branches of government will all invariably follow, whatever the personal preferences

26 Kramer $(2007,703)$.

27 Pettit $(2012,153)$.

28 PetTit $(2012,154)$.

29 PetTit $(2012,154)$.

30 Pettit $(2015,691)$.

31 Kramer $(2007,749)$ (My emphasis). 
of their members". ${ }^{32}$ But one point made against judicial supremacy is that, even if judges decide to align their preferences to that of the public, ${ }^{33}$ the influence of the public is not dispositive. It depends on the willingness of judges to accommodate their views to that of the public.

Kramer cannot have it both ways. Instead of trusting that "[o]n any issue that captures the public's attention, where the majority goes is where government policy will go", ${ }^{34}$ he should have elaborated on specific ways by which that adaptation of officials' views to that of the public does not depend on willingness of the former. Otherwise, citizens lose control and capacity to determine the direction of constitutional policies and are thus rendered unfree.

\section{B. Donnelly's "people's veto"}

Donnelly advocates a "people's veto", a mechanism for reconsidering constitutional decisions made by the US Supreme Court. This, he claims, would promote "ongoing constitutional engagement among average citizens" ${ }^{35}$

The process would work by sending to Congress cases decided by the Supreme Court by a five-to-four majority. Congress would then have an up-or-down vote on public reconsideration. Should Congress vote for reconsideration, the case would then be sent to the American people who would dictate the outcome by a referendum. ${ }^{36}$

To make sure that the final decision is made based on considered views of the people and to "minimize the likelihood that the American people decide the issue based on a snap judgement, or while in a public frenzy", the mechanism must "allow sufficient time between the Court's decision and the national referendum to allow for sober deliberation". ${ }^{37}$

Some criticisms are in order. First, popular constitutionalists' rejection of judicial supremacy is at odds with how the mechanism is supposed to be triggered. Inasmuch as it starts in judicial procedures, the court-centrism that popular constitutionalists criticise is reaffirmed by positioning the ignition of debates on constitutional matters in courts rather than in other institution or agent. This means that, initially, the constitutional issue to be debated still has to be framed in judicial-legal terms. This has an additional consequence: one should be wary of extending the effects of judicial decisions to the entire society. The contexts in which trials initiate are limited to problems affecting concrete individuals. Hence, additional reasons must be provided to consider the conversational context of those trials as relevant for an interpretation

Kramer $(2007,750)$; Kramer $(2004 b, 970)$.

34 KRAMER $(2007,750)$.

35 Donnelly $(2012,187-188)$.

36 Donnelly $(2012,188)$.

37 Donnelly $(2012,188-189)$. 
affecting the whole society. ${ }^{38}$ Individuals who were not parties at the trial at hand, could legitimately ask why their normative status has been altered by an issue with which they had nothing to in the first place. Put in republican terms, they lack control over something that affects them as members of a collective unit. As a result, they are rendered unfree.

Second, it is not obvious that the time given to the citizenry between the court's decision and their reconsideration will suffice to form an informed and principled judgement on the issue under discussion. It is not obvious either that those results will be reached in the absence of additional institutional structures facilitating deliberation among individuals, about which Donnelly is silent.

Third, it is not clear why the mechanism is reserved to five-to-four $\mathrm{Su}$ preme Court decisions. Donnelly seems to assume that divisions among justices somehow amount to social divisiveness outside the court. We know, however, that is not the case.$^{39}$ Also, this sort of mechanism could give judges incentives for engaging in pork-barrelling practices.

The people's veto may be a way of reducing the court's power, but it fails at justifying why ongoing constitutional meaning imposition should be triggered judicially and be dependent upon the inner politics of a court that is not a representative institution in the first place.

\section{Pozen's "judicial elections"}

Pozen wants to show "what judicial elections are capable of - to clarify a plausible ideal against which they might be evaluated and in pursuit of which they might be engineered"..$^{40}$ Judicial elections, in his view, would help sustain the democratic legitimacy of constitutional law in a more persistent and nuanced way than traditional reform mechanisms.$^{41}$ They would do this for reasons related to the electors and to the judges. I am interested in the second.

Elections would foster virtues inside the courthouse in three ways: judicial restraint, judicial populism, and role fidelity. Pozen uses the term 'restraint' as a regulative ideal for the judicial function "aimed at minimizing interference with the political process". ${ }^{42}$ This restraint would depend on different factors related to the political and electoral incentives of the actors involved. ${ }^{43}$ First, "through the types of jurisprudes favored by the electorate" ${ }^{44}$ so that

38 The expression "conversational context" is MARMOR's $(2014,149)$.

39 Gargarella $(1996,181)$; Waldron $(2016,256-257)$.

40 Pozen $(2010,2066)$.

41 Pozen $(2010,2072)$.

42 Pozen $(2010,2077)$.

43 Pozen $(2010,2077)$.

44 Pozen $(2010,2077)$. 
the court's composition is tied to the voters' preferences. The court is likely to restraint itself if its members profess some form of judicial minimalism. Second, judges may be prone to restraint themselves if they consider that this is what the public desires, so that they can keep their job. This is supported by literature that shows ways in which judges are responsive to their institutional environment. ${ }^{45}$

Regarding judicial populism, that is, the adaptation of the judges' views of the law to those of the public, Pozen argues that there are two ways in which such deference could be implemented. The first is the standard prescription in the literature, namely, "cede as much ground as possible to the coordinate branches" ${ }^{46}$ But Pozen considers an additional option: "that the judge [incorporates] into her decision-making calculus the beliefs of the citizenry, to the extent she can perceive them, irrespective of what the legislature or executive has done"; ${ }^{47}$ to "mirror popular views" ${ }^{48} \mathrm{He}$ calls this majoritarian judicial review. ${ }^{49}$

Yet, the proposal echoes the problem evinced by the authors previously discussed. That is, the insistence on turning the judiciary into a more popular and political institution. The focus should be on the effects a decision would produce on the context against which potentially affected persons receive its effects. Courts are limited in their capacity to grasp preferences different than the ones expressed in the cases brought before them. This is normal, for they are not representative institutions, which means that majoritarian judicial review is really an oxymoron..$^{50}$

Regarding role fidelity, Pozen examines whether the judges' selection method influences how they decide cases. Pozen suggests that judicial elections could have the effect of sending judges a signal that consideration for "public opinion is part of the job description". ${ }^{51}$

These approaches striving to make the judiciary more receptive to majoritarian concerns, to democratise it, as it were, strike me as odd.$^{52}$ If courts are countermajoritarian forces in a democracy, and if they are given powers to control that majorities decide within the limits of the law and not just having electoral incentives and party politics in mind, why is it that Pozen's reaction is to introduce democratic features in the judiciary? Why not working

45 Hanssen $(1999,415)$; Pozen $(2010,2078)$.

46 Pozen $(2010,2080)$.

47 Pozen $(2010,2080)$.

48 Friedman $(2003,2598)$.

49 An approach defended by Bonneau $(2009,15)$, although Pozen rightly points out that this prescription is not novel. See the literature he cites in $(2010,2081)$. For a similar approach, see Post \& SiEgel $(2007,390-391)$.

50 Gargarella $(1996,181)$.

51 POZEN $(2010,2084)$.

52 And others as well. See Atria 2000. 
on improving mechanism of representation or democratic mechanisms more generally, instead?

It is not surprising, then, that Pozen does not delve on how and why the citizenry would deliberate on constitutional matters at the level of the informal public sphere. He expects that judges will adapt their views to the of the people. But those views need to be formed and expressed somehow, and nothing in Pozen's proposal tells us how the people would manifest their preferences in a judicial election. In the absence of those deliberative suggestions, the election model remains an aggregative scenario and, in these models the transmission of information from the politicians to citizens is generally asymmetrical..$^{53}$

III. REPUBLICAN, DELIBERATIVE, AND EGALITARIAN

PROPOSALS FOR POPULAR CONSTITUTIONALISM

This section suggests measures for the implementation of popular constitutionalism: contestation without erga omnes effects, commonwealth constitutionalism's judicial review, parliamentary deliberation and justification, and interpretive constitutional mini-publics.

\section{A. Contestation without erga omnes effects}

Contestatory mechanisms give citizens the role of invigilators of law through the possibility of recursion, encouraging them to be "alert to any possible misdoing and ready to challenge and contest the legislative, executive and judicial authorities". ${ }^{4}$

The judiciary is perhaps the best example of a contestatory mechanism. Courts provide the space for individuals to make claims about what they think the constitution means, and how those interpretations affect them. Judicial systems thus ensure that individuals are neither vertically nor horizontally dominated.

I agree with Pettit on this point. Forums of contestation are necessary to keep government and other individuals from impinging upon the liberty of subjects and, indirectly, provide them with tools to guide and control the direction of governmental policy (reference redacted). Yet, Pettit does not properly justify why he limits his account to contestation, and why he shows a distrust towards mass participation and deliberation, discarding them as relevant for the protection republican freedom. ${ }^{55}$ Republicans have good reasons to value and rely on a participatory citizenry: civic engagement is one element among others allowing for the vigilance demanded by republicanism.

53 OVEJERo $(2002,167-170)$.

54 Petrit $(2012,14,215)$. Here, Pettit's reference to judicial authorities must be generally understood, in my view, as courts exercising judicial review.

55 For a view supporting this statement, see MсCоRмIск 2011, 152. 
Models that limit vigilance and final control to contestation are also impeded in justifying judicial decisions with erga omnes effects. Those, like Pettit, who would circumscribe activism to contestation cannot at the same time justify giving contestatory institutions like courts the role of final authoritative agents in the determination of what counts as binding for the entire society without dealing with other sorts of problems that cannot be tackled through contestation alone. ${ }^{56}$

Contestation can only indirectly steer the direction of governmental policy, for it is mostly a mechanism of reactions, not of action. It is meant to resist norms and policy and, through that resistance, to influence them.

In Pettit's view, contestation in the public sphere needs a distribution of labour among citizens based on expertise and organisation, a proposal which I endorse as a necessary, not a sufficient condition:

What is needed, obviously, is specialization and organization: in short, a division of labour in the exercise of civic vigilance. And that ideal is scarcely unrealistic, since contemporary democracies naturally give life to watchdogs, activist bodies - non-governmental organizations - that operate locally, nationally and internationally across the various domains of political life. These include bodies that specialize, for example, in consumer issues, people's working conditions, women's rights, environmental institutionalized, racial equality, opportunities for the disabled, the conditions of prisoners, gay and lesbian rights, health provision and public education..$^{57}$

As I have said, I agree with Pettit that this is a necessary condition for securing individuals' liberty. On the courts' side, their contribution to an unconditioned individualised system of influence is mostly found at this level of contestation. Individuals that go to court to claim that they are being affected by some form of either vertical or horizontal domination need to frame their grievances in accordance to the set of existing sources available for judges to employ. In principle, as much leeway as they could have in interpreting constitutional norms, the judges' primary task is not to advance or create policy, but to apply those that are already in place. Deviations from that principle can be explained, but they are more difficult to be justified and, in any case, they cannot be presented as manifestations of the judicial duty to dictate what the law is but as an additional role granted in virtue of their countermajoritarian nature. The onus falls on those who welcome strong judiciaries.

There are good examples of the sort of procedures that would help citizens to air their own interpretations of the constitution in courts are those

56 This is at the core of McCormick's criticism of Pettit $(2011,154)$.

57 PetTit $(2012,226)$. 
generically known as writs of amparo, like the ones found in the Chilean, ${ }^{58}$ Argentine, ${ }^{59}$ Mexican, ${ }^{60}$ Brasilian, ${ }^{61}$ and German constitutions.${ }^{62}$ These grant individuals with a procedure for the protection of constitutional rights, which are more informal in their processing than more ordinary procedures, and have priority in the courts' dockets. Procedural differences aside, these writs allow individuals to pursue relief from a court when their constitutional rights are infringed upon or endangered by an act or omission of a governmental authority or another individual. To take Chile as an example, these procedures have proven to be highly effective for the protection of a number of constitutional guarantees. ${ }^{63}$

These procedures meet Pettit's condition that systems of influence ought to be individualised, unconditioned and efficacious ${ }^{64}$ but they do not put citizens as main actors in the generation of collective norms and policies, including those created interpretively. In short, this section does not recommend mechanisms that are not currently available in different polities. My suggestion is, rather, that a republican, deliberative and egalitarian popular constitutionalism should, as a minimum, include these sorts of devices. Nevertheless, additional mechanisms are required.

\section{B. Commonwealth models' institutions}

The commonwealth model of constitutionalism, sometimes referred to as the "parliamentary model" ${ }^{65}$ is an "intermediate model of constitutionalism that, in somewhat different versions, has been adopted in Canada, New Zealand, and the United Kingdom as an alternative to their traditional principle of parliamentary sovereignty". ${ }^{66}$ The model consists in the "combination of two novel techniques for protecting rights. These are pre-enactment political rights and weak-form judicial review" ${ }^{67}$ The first asks elective branches of government "to engage in right review of a proposed statute before and during the bill's legislative process". ${ }^{68}$

The second technique, weak judicial review, decouples judicial review from judicial supremacy, meaning that although courts have powers of constitutional

58 Article 20 of the Chilean Constitution.

59 Article 43 of the Argentine Constitution.

60 Article 103 of the Mexican Constitution.

61 Article 150 of the Brasilian Constitution.

62 Article 93 Sec. 1 Nr. 4 of the German Constitution.

63 Couso $(2005,74)$. The procedure can only be used to protect first generation rights. Socio-economic rights are excluded.

64 Petтit $(2012,209-238)$.

65 HIEBERT (2006).

66 GardBaum $(2010,167-168)$.

67 Gardbaum $(2013,25)$.

68 Gardbaum $(2013,25)$. 
review, they do not necessarily or automatically have final authority on what the law of the land is. ${ }^{69}$

This is not exclusive to commonwealth models for these features have been advocated for by popular constitutionalists as well. Gardbaum argues, however, that the Commonwealth model is innovative and distinctive in at least three ways. First, weak forms of judicial review are the general rule in the exercise of the court's powers, whereas in popular constitutionalists' models the supremacy of other branches of government is" triggered only exceptionally or only periodically". ${ }^{70}$ Secondly, models of popular constitutionalism do not include the exercise of a legislative override power. In these accounts, courts either defer to the relevant branch or it is the citizenry the one holding the final say. By contrast, commonwealth models provide "a far more tangible and concrete institutional mechanism of judicial non-finality". ${ }^{71}$ Thirdly, two of the model's mechanisms - Canada's constitution 'notwithstanding clause and the UK Supreme Court's power to issue declarations of incompatibility - "were entirely novel when introduced". ${ }^{72}$

Yet, even though they represent an improvement and a contribution to popular constitutionalism, commonwealth mechanisms need additional measures, for even though they represent a is a non-supremacist form of judicial review, their exercise in practice "seems to make little difference to the role or influence of [strong] judicial review vis-à-vis the legislature". ${ }^{73}$ In the case of the United Kingdom, Bellamy argues, although ministers are forced to issue a declaration of compatibility of legislation with the Human Rights Act and, in spite of the provisions for prior legislative scrutiny of such claims, "it is ultimately judicial review by the judges sitting in the relevant courts which decides the issue". Consequently, "legislators come under pressure to anticipate the court's ruling rather than to elaborate a view of their own". The Canadian experience with the use of the notwithstanding clause exhibits similar patterns. ${ }^{74}$ This calls for additional measures.

\section{Parliamentary deliberation and justification}

Argumentation and justification are features generally present in judicial procedures, but largely absent in the legislative field.$^{75}$ As it happens, those who extol representative institutions vis-à-vis judicial institutions, tend to

69 Gardbaum $(2013,26-27)$.

70 Gardbaum $(2013,29)$.

71 Gardbaum $(2013,29)$; Hiebert $(2006,7,13)$.

72 Gardbaum $(2013,29-30)$.

73 Bellamy $(2007,47)$.

74 Bellamy $(2007,47-48)$.

75 Waldron 1999; Wintgens 2006; Pintore 2010,36; Marcilla 2010, 103; Oliver-Lalana 2016, 7 . 
frame their arguments in abstraction, mostly at a theoretical level. By contrast, a great deal of sophisticated scholarship has been elaborated on judicial argumentation and justification..$^{76}$ By contrast, we lack accounts studying the role of parliament in the process of constitutional deliberation. ${ }^{77}$

Some scholars have taken up this challenge and attempted to elaborate a theory of legislative argumentation under the label of legisprudence, that is, broadly described, a legal theory that accounts for the principles underlying the activity of the legislator. Legisprudents seek to develop those principles as well as the ways in which our expectations that legislators put forward, debate, and weigh the reasons for which they pass laws, become a reality.

According to Oliver, three theses justify this expectation. The first is a normative thesis that says that inasmuch as they are the product of collective decision-making, "every law can be taken to entail a claim to justifiability which cannot be fulfilled with whatever motives, but calls for good reasons and hence requires an argumentative process for these to emerge" ${ }^{78}$ The second is that legitimacy is not binary but rather a

gradual and compound magnitude that does not get exhausted in the actual working of democratic procedures and the legal form given to statutes, for it is also bound up with the arguments supporting them, in particular with the ones publicly adduced in parliament as the institutionalized centre for lawmaking. ${ }^{79}$

Thirdly, there is a link between the quality of a law and its underlying reasoning. This means that the better the argument for a decision, the higher its quality. ${ }^{80}$

Legisprudents thus show that there is no principled reason to discard parliaments as constitutional deliberators and, as it happens, given their representative role, that there are normative reasons to claim that they should engage in deliberation and to demand that they justify their decisions. We should expect this from our representatives. ${ }^{81}$

Hence, legisprudence ties the rationality of legislative production to deliberative considerations, broadly defined.$^{82}$ The question is, then, what is it that guarantees the deliberativeness of the process. These authors are adamant that some argumentative conditions inside parliament must obtain to achieve a deliberative minimum. They also rightly underscore the potential that legislative justification has for the legitimation of the state's normative production in

76 For example, Alexy 2003a; 2003b; Beatty 2005; Barak 2012; Schlink 2012.

77 Oliver-Lalana $(2016,9)$.

78 Oliver-Lalana (2010, 3-4).

79 Oliver-Lalana $(2010,4)$.

80 Oliver-Lalana $(2010,4)$.

81 WALDRON $(2009,352)$.

82 SiecKMANN (2010, 71-72). 
general, an emphasis which strengthens the case for the including the legislator within the scope of legal and not just political actors. ${ }^{83}$

Yet, the effort can be taken one step further. The normative premises of legisprudence are compatible with extending the scope of legal theory not only to Parliament or to representative institutions more generally, but to the broader public sphere. Legisprudents, however, neglect exploring further links between parliaments and the citizenry, not only in terms of legitimacy, but in terms of the citizenry's capacity to deliberate by itself or to be part of a deliberative process that contributes to the legitimation of the decisionmaking system they are part of. This marks an important difference between the legisprudential project and my own: legisprudents generally circumscribe their reflections to parliament. ${ }^{84}$ This is an unnecessary restriction. I also believe the difference lies in the ways both projects conceive of the notion of representation: for legisprudents, representation is a necessary evil, as it were. Considerer, for example, Tschentscher et al.:

Decisions by majority are a necessary restriction, not a fulfilment of discursive ideals. Equally, limiting parliamentary debates to elected representatives is only an approximation to the ideal of universal participation: if we have to rely on participants, we can at least try to keep that group as diverse as possible. Deliberative democratic theory should, therefore, focus neither on outcomes nor on representation. ${ }^{85}$

This is a mistake. Although the relationship between representation and deliberation is admittedly tense, ${ }^{86}$ representation is not only a tool for coping with practicalities of scale: it is an actual means for channelling discourse. This is a more charitable and more compelling understanding of representation. I suggest that the extension of this project beyond parliament can be made by relating the demands of legislative justification with this charitable interpretation of representative government on the one hand, and with the demands deliberatively expressed by the citizenry on the other.

In this context, I find Urbinati's account of representation as advocacy particularly illuminating. In her words, speech is "a means of mediation that belongs to all citizens, linking them and separating them at the same time [...]. It gives meaning to voting, which presumes evaluation and discrimination among articulated opinions [...]. Thus, it is not indirectness per se that distinguishes representative democracy from direct democracy" ${ }^{87}$ Rather, it is their lack of simultaneity. Judgement and resolution in modern democracies

83 Wintgens $(2006,5)$.

84 Wintgens (2006); SieckManN (2010); Oliver-Lalana (2016; 2010).

85 TSCHENTSCHER et al. $(2010,14)$.

86 Bohman (2012, 76); PARKinson $(2006,5)$; SchäFer $(2017,1)$.

87 Urbinati $(2000,765)$. 
take place at separate times, but not in disconnection to each other. This entails that representation is not only a solution for a practicality, but an actual means for citizens to voice their preferences.

This is absent in accounts providing philosophical foundations for legisprudence. Wintgens', perhaps the most elaborated account available in the literature, challenges the notion of legal theory as a construction that focuses on adjudication rather than promulgation, in the judiciary rather than in the legislature,$^{88}$ but he does not address the problem of what sort of justification could/should be considered not only rational by those potentially affected by the legislators' decisions, but legitimate as well. In my view, the requirement that decisions made by legislatures ought to be justified, has a particular strength at the constitutional level: when justifying a decision with bearings on constitutional matters, when such a decision changes the constitution in some way, a duty to provide specific justifications for the interpretation of what the constitution means is brought about. The reason is that impositions of meaning and explicit changes to the constitution represent an alteration of the most basic terms of the social contract. Those terms are ultimately the reasons why representatives gain their authority over their subjects in the first place, and why subjects would find acceptable to endorse the norms that are being imposed on them by legislators.

Habermas' two-track model as well as deliberative systemic approaches resonate in this double extension of the legisprudential demand for legislative justification. The relationship between the formal and the informal public sphere is better accounted for if one abandons the idea, exemplified by Tschentscher et al.'s quote above, that representation is just a practical tool for dealing with scale, space and time constraints and if one understands the concept as an enabler for deliberation.

The question is, then, what sort of framework would be optimal for assessing the type of conversation that would transmit deliberations taking place in the informal public sphere to parliaments, in ways that parliamentary deliberations represent individual not only territorially, but discursively as well. Such a framework would make deliberative democracy and legisprudence compatible to each other.

The compatibility between these concepts and theories is something that has yet not been explored. This is the case in legisprudence and its linkage to deliberation outside parliaments, but is it also the case with deliberative democracy. Consider Boswell et al's contention that "beyond ideal theoretical prescriptions, we still know very little about if and how [...] different deliberative sites link together, and how they constitute an inclusive deliberative system in practice" .89

88 Wintgens $(2006,4-8)$.

89 Boswell et al. $(2016,264$; also SCHÄFER $(2017,3)$. 
These authors give me a starting point to draw a sketch of what a deliberative legisprudence should look like. On the one hand, I endorse Schäffer's suggestion that we should avoid making assumptions about the ethical orientation of deliberating actors to our concepts of deliberation..$^{90} \mathrm{He}$ is led to this conclusion because incorporating those ethical motivations into our concepts of deliberation "produces blind spots in our analytical tools that hinder us from capturing important aspects of deliberative practice, such as more contentious forms of deliberation", ${ }^{91}$ and because actors' motivations vary across different contexts.

This distinction is especially relevant for parliamentary contexts, as legislators discharge their duties in a network of incentives that lead them to enter debates with strategic and positional stances, while asking them to discuss and debate with the counterparts about the matters they are to legislate about.

This dynamic of incentives I beneficial from a deliberative democratic point of view. Legislators, while acting strategically and trying to advance the position of the parties they are part of, they do so in ways that must appeal to the views of those individuals they represent or try to represent. So, the main question is not how to avoid strategic behaviour in parliamentary deliberation, but how to make sure that legislators are indeed influenced by the citizens' arguments and preferences.

On the other side of the tension, the next point will elaborate on how the views of citizens are formed through deliberation. One way of approaching this problem is by relying on Habermas' idea of translation, a term he first rejects as inadequate to describe the special relationship that law has with the lifeworld. The latter's autopoetical reproduction and linguistic specialisation constructs the law's own image of the world. But then, Habermas acknowledges, law is "supposed to 'influence' general social constructions of reality, and in this way influence those other discursive worlds as well". ${ }^{92}$ The initial rejection of the concept is due to the role it plays in systems theory, a construction that, in Habermas' view, is not consistent with understanding law as a hinge between the lifeworld and the rest of the subsystems. ${ }^{93}$

Translation takes a more positive form afterwards, as Habermas incorporates it to reject paternalistic interferences of the bureaucratic system into civil society:

In spite of asymmetrical access to expertise and limiting problem-solving capacities, civil society has the opportunity of mobilizing counterknowledge and drawing on the pertinent forms of expertise to make its own translations. ${ }^{94}$

94 Habermas $(1996,372)$. 
This at the core of Habermas' two-track model of democracy, in which "formally institutionalized deliberation and decision must be open to input form informal public spheres". ${ }^{95}$ Nevertheless, the transmission from one track to the other is still a problem for deliberative democrats. With this in the background, I will rely on Boswell et al.'s to explain how transmission could operate in practice.

Transmission "places the emphasis on the connections between the various components that that make up deliberative systems, particularly between public and empowered decision-making sites". ${ }^{96}$ Boswell et al.'s analyse three mechanisms of transmission between individual agency at the level of the public sphere and formal institutional structures: middle democracy, democratic innovation, and discourses. The first, middle democracy, is a notion taken from Gutmann \& Thompson, ${ }^{97}$ according to which actors pursue matters of common interest through more traditional institutional spaces conceived of to link the citizenry with public authorities (e.g., public hearings, legislative inquiries).$^{98}$ The second, involves the notion of coupling, which describes connections between different (formal and informal) institutions and practices, which ideally would involve " processes of convergence, mutual influence and mutual adjustment" such that "each part would consider reasons and proposals generated in other parts". ${ }^{99}$ Metaphorically, "coupling draws our attention to the nature and strength of relationships between different parts in a deliberative system, and to the spaces that might develop in-between". ${ }^{100}$ The third refers to a broad ensemble of ideas, categories and metaphors which may enable actors across the system to draw on as shared argumentative resources..$^{101}$

Boswell et al. conclude that transmission can occur via any of the three aforementioned mechanisms, ${ }^{102}$ that those avenues are not mutually exclusive, and suggest that current political institutions have the potential to enable transmission. The implication is that no significant changes would be necessary to operationalise transmission in a meaningful way. ${ }^{103}$ Moreover, that transmission does not only take place when there is correspondence between deliberation in the public sphere and the one taking place in formal empowered spaces. This, they argue, is at once too restrictive, for there are other forms of transmission besides policy impact, and too naïve, as "discursive

95 Rehg (1996, xxxi).

96 Boswell, Hendriks and Ercan $(2016,264)$.

97 GutMann and THOMPSOn (1996).

98 Boswell, Hendriks and Ercan $(2016,265)$.

99 Mansbridge, Bohman et al. $(2012,23)$.

100 HeNDRIKS $(2016,44)$.

101 Boswell, Hendriks and Ercan (2016, 265); Dryzek (2009).

102 Boswell, Hendriks and ErCan $(2016,276)$.

103 Boswell, Hendriks and Ercan $(2016,276)$. 
affinity does not imply a substantive impact". ${ }^{104}$ The study suggests that some semiformal spaces like commissions of inquiry or parliamentary committees "offer crucial mechanisms of transmission between informal public opinion (public space) and formal decision-making cycles (empowered space). ${ }^{105}$

Yet, the study also shows that, notwithstanding their potential as deliberative enablers, "relying on the existing institutional architecture may not always be sufficient" because "[s]ome deliberative systems [...] will continue to feature exclusionary discourses and norms that do not recognize the legitimate meaningmaking power of counter publics, and for which there is no easy institutional fix". ${ }^{106}$ Here, the role of mini-publics becomes relevant, given their capacity to bring together actors from the public sphere to a semi-institutionalised setting, they create the space to open up issues usually dominated by elites and expert policy makers and, in doing so, offer "a vital dose of democratic inclusivity, rendering the otherwise hidden or implicit value assumptions more visible, and transmitting lay perspectives on these that can challenge the status quo". ${ }^{107}$

\section{Constitutional mini-publics}

Boswell et al.'s conclusion regarding the role of mini-publics in deliberative systems is both challenging and encouraging. It calls for the development of democratic innovations that open up spaces of interaction among citizens where they may debate about any issue they consider as relevant for the community, in coexistence with existing formal institutions. As it happens, the list of mini-publics and deliberative fora operating in this middle ground between the informal public sphere and formal decision-making public institutions is vast. ${ }^{108}$ On the one hand, this limits my capacity to determine with accuracy just how much complexity can be dealt with by employing mini-publics. On the other, this variety shows that there seems to be no limitation on the topic and type of subject that can be deliberated on through mini-publics, constitutional matters included.

I am more concerned with some broad features and not with the precise configuration and fine-grained practical operation of some specific minipublic which would somehow incarnate popular constitutionalism. Most mini-publics share a number of common features, for example, in the way they select their participants and in their procedures. I now elaborate on these aspects of a possible constitutional deliberative mini-public.

104 Boswell, Hendriks and Ercan $(2016,279)$

105 Boswell, HendriKs and ErCAN $(2016,276)$.

106 Boswell, HeNdriKs and ERCAN $(2016,277)$.

107 Boswell, Hendriks and ERCAN $(2016,277)$.

108 Consider, for example, Chambers (2003); Fung (2003); Goodin \& Dryzer (2006, 221 225); Delli Carpini, Lomax Cook \& Jakobs (2004); Schkade, Sunstein \& Hastie (2010); R yan $\&$ Sмттн $(2014,12)$. Also consider the staggering number of studies uploaded to participedia.net. 


\section{Selection methods}

Regarding selection methods, there are roughly three methods employed in mini-publics: self-selection, random selection, and stakeholder selection. Following Button \& Ryfe, selection methods must answer two questions: who initiates the deliberative procedure, and who participates. Regarding the first, these authors found that three kinds of entities typically initiate a deliberative encounter: "grassroots civic groups, such as neighbourhood associations; nongovernmental organizations (NGOs) [...]; or government organizations". Similarly, there are three "basic kinds of participation selection schemes: self-selection, random selection, and [...] stakeholder selection". The first two are self-explanatory. Stakeholder selection "involves organizers in a process of identifying groups likely to be affected by a decision and issuing a formal invitation to representatives of these groups". ${ }^{109}$

I submit that an appropriate mini-public for constitutional deliberations should select its participants primarily by random selection, and it should be initiated, in Button \& Ryfe's vocabulary, by governmental organisation.

Moreover, the republican thrust of this proposal would also justify a duty to participate, unless justifications are provided. ${ }^{110}$ This does not exclude that some stakeholders may participate as such in the deliberations, in the same way that some organisations go to courts as amicus curiae. Random selection allows us to with some problems raised by alternative methods. It solves the problem that in self-selection schemes, individuals require more motivation and incentives to enter the process, and they would be more prone to abandon the process to the extent their initial motivations and incentives disappear they may exit with relatively little cost. Moreover, self-selection would likely incorporate more politicised individuals with less willingness to change positions, which in the extremes would make the deliberative process superfluous, or polarised, to the extent that most members think alike. ${ }^{111}$

Random sampling has an egalitarian appeal lacking in alternative selection methods. ${ }^{112}$ Additionally, "[w]ith modern random samples, we can know a great deal about the chances that our sample is giving us the same results as those we would have gotten had we asked the entire population". ${ }^{113}$ Moreover, random sampling is beneficial because, first, framing issues are less likely to emerge, given that participants are free from pressures of competitive reelection. Second, randomness avoids the effects of self-selection, "which will

109 Button \& RyFe $(2005,23)$.

110 Like with compulsory voting, this is an issue that I leave aside and take as a given in this discussion.

111 Sunstein (2002); Schkade, Sunstein and Hastie (2010).

112 HENDRIKS $(2005,82)$.

113 FishKIN $(1997,44)$. 
often bias participation toward those who are heavily invested in positions that come with problematic frames attached". Third, representative cross-sections of the population are more likely to multiply reflective and irreflective claims [frames], and "dilute opportunities for frame-based coalitions". ${ }^{114}$

Of course, random sampling is no panacea. No sampling method can be completely representative of the entire population. Besides, the egalitarian appeal of these mechanisms wanes in the absence of corrective methods for the selection process (e.g., quotas). Yet, random samples and selections are still a very attractive choice for institutionalising a deliberative societal mechanism of constitutional interpretation, because this shortage in the representative capacity of random sampling methods is stronger the smaller the deliberative body. Contrariwise, the bigger the sample, the more representative the mini-public. ${ }^{115}$

I must leave the question of the total number of participants necessary for my proposal unanswered as this is an issue that will depend on the size of the polity in which the mini-public is being implemented. Some indications in the literature range from Dahl's recommendation of 1000 citizens for an population of roughly 246 million, ${ }^{116}$ to Ackerman \& Fishkin's 500 for a population of roughly 292 million, ${ }^{117}$ or Gosh's 200 for a population of roughly 22 million. ${ }^{118}$ There is nothing sacrosanct about these numbers, but given the aforementioned benefits of random sampling when the sample is higher, higher numbers are to be preferred to smaller ones.

That the mini-public is organised by government means that it must be created by law and that it must operate on a regular basis. As to when, how often and for how long, I suggest the body should gather during congressional election year, right before the legal and official beginning of electoral campaigns. This would provide those running for office with incentives to make their own views explicit, and participants with a sense that what they do matters, that both incumbents and campaigners listen and pay attention to their contribution, for they have electoral incentives to do so. ${ }^{119}$ This coincides broadly, for example, with Ackerman \& Fishkin's idea of celebrating Deliberation Day two weeks before national elections, ${ }^{120}$ but more discussion on this point is needed.

114 CALVERT \& WarRen $(2014,212)$.

115 BäChtiger, SETäLA \& GRÖNDLUnd $(2014,230)$. Consider, for example, Hendriks study on consensus conferences and planning cells: "[w] hen sample sizes are larger [...] simple random sampling is usually employed and no adjustments are made to the sample to meet predetermined quotas". HENDRIKS $(2005,82)$.

116 DAHL $(1989,340)$.

117 ACKERMAN and FISHKIN (2004, 24-25).

118 Gosh $(2010,346)$.

119 Chambers $(2012,68)$.

120 ACKERMAN and FishKIN $(2004,23)$. 


\section{Procedure}

A constitutional minipublic that provides spaces for ordinary citizens to deliberate about the meaning of their constitutions ought to be structured in ways that they put interpretive problems at the centre. This means that participants must be aware that their deliberations and their result do not constitute a decision in a strong sense of the term, that those deliberations and their results are interpretive, that is, that participants do not deliberate about the merits of changing or repealing constitutional norms but to provide them with meaning, and that the results of those deliberations will be transmitted to their representatives who, in turn, are mandated to take them into account in the justifications they provide for their legislative activity.

The non-decisional, non-binding nature of the procedure can be established by legal fiat. A law or a constitutional provision creating an interpretive and deliberative mini-public would limit its competences to debate about interpretations. Additionally, it would establish the duty for parliamentarians to justify their normative production appealing to the interpretive understanding of the people resulting from the deliberations in the mini-public.

But agendas play a role as well. An interpretive constitutional deliberative minipublic would be different from other democratic innovations. For example, traditional deliberative polls discuss matters previously selected by a leading convenor (Fishkin \& Farrar 2005, 73). In interpretive constitutional deliberation the range of topics would be initially determined by the content of the constitution under debate. Convenors should have some leeway in the choice of topic within the limits of what is seen as a constitutional matter in the polity at hand.

Exactly what issues should be selected for interpretive discussion will depend also on the specific constitutional tradition. Some countries are in need of discussing some issues, some countries others, and the determination of which issue is more urgent is usually determined by political practice. Convenors should be aware of this.

The specifics of the deliberative procedure may vary, but I am sympathetic to the use of some versions of deliberative polling. In advance of the event, participants should be sent background material presenting them with a range of information and viewpoints on the interpretive matters to be discussed..$^{121}$ Also, their basic structure would include small-groups discussions, as well as the opportunity to come together as a large group in plenary sessions. In traditional deliberative polls, participants here have possibility to ask questions to an expert panel. I do not discard this, but in my design, the presence of representatives in that panel would be important, as this would permit 
incumbents as well as those running for office to be in direct contact with participants and their deliberations. These would "help elites make decisions that have deliberative legitimacy". ${ }^{22}$

The experiment would also include the administration of a final survey, whose results would then lead to a report that would be sent back to Congress.

\section{And back to transmission}

The results of discussions ought to be sent to parliamentarians for their mandatory use in legislative discussions and justification of decisions with bearings on constitutional law to the extent they refer to the discussions undertaken in the imagined mini-public. As I have argued above, members of parliament should incorporate these results explicitly in the Bills they propose and in the laws they pass. They may not agree with those interpretations, with how participants in the imagined mini-public think, with the likely consequences of the implementations of their interpretations, or with any other aspect resulting from the engagement with the results obtained. Their duty is to explicitly consider them in their deliberations and in the justification for their decisions whether they agree or disagree with them.

\section{CONCLUSIONS}

This paper undertook three tasks. First, sketched the principles grounding my understanding of popular constitutionalism. It then made exposed the flaws observed in some of the most articulate accounts attempting to make such project feasible. Finally, it shed lights on what a republican, deliberative, and egalitarian popular constitutionalism would look like. The specifics of the institutional design may vary, needless to say, and they certainly require more elaboration, but it is fair to say that it is compatible with the republican, deliberative and egalitarian principles here endorsed. This contributes to a body of literature in need of a revival.

\section{REFERENCES}

Ackerman, Bruce y James S. Fishrin. Deliberation Day, yup, New Haven \& London, 2004.

Alexy, Robert. Constitutional Rights, Balancing and Rationality. Ratio Juris, 16: 2, 2003a: 131-140.

Alexy, Robert. On Balancing and Subsumption. A Structural Comparison. Ratio Juris 16: 4, 2003b: 433-449. 
Alterio, Ana Micaela \& Niembro, Roberto. Constitucionalismo popular en Latinoamérica, México DF: Porrúa, 2013.

Atria, Fernando. Revisión judicial: el síndrome de la víctima insatisfecha. Estudios Públicos, 2000: 347-402.

Bächtiger, André, Maija Setäla \& Gröndlund. Towards a New Era of Deliberative MiniPublics. In Grönlund, Kimmo, André Bächtiger \& Setälä, Maija (eds.). Deliberative Mini-Publics. Involving Citizens in the Democratic Process, ECPR Press, Colchester, 2014: 225-245.

Barak, Aharon. Proportionality: Constitutional Rights and Their Limitations, Cup, Cambridge, 2012.

Beatty, David M. The Ultimate Rule of Law. oup, Oxford, 2005.

Beaumont, Elizabeth. The Civic Constitution: Civic Visions and Struggles in the Path Toward Constitutional Democracy, oup, Oxford, 2014.

Bellamy, Richard. Political Constitutionalism. A Republican Defence of the Constitutionality of Democracy, cup, Cambridge, 2007.

Bello, Donald E. Against Judicial Supremacy in Constitutional Interpretation 31 (2017a): $7-28$.

Bello, Donald E. Deliberation and Courts: The Role of the Judiciary in a Deliberative System, Theoria: A Journal of Social and Political Theory 152 (64), 2017b: 77-103

Bello, Donald E. Republicanism, Deliberative Democracy, and Equality of Access and Deliberation, Theoria (Wiley) 84 (1), 2018: 83-111.

Bohman, James. Epistemic Value and Deliberative Democracy. The Good Society 18 (2) (2009): 28-34.

Bohman, James. Public Deliberation. Pluralism, Complexity, and Democracy. The mit Press, Cambridge, Massachusetts; London, 1996.

Bohman, James. Representation in the deliberative system. In John Parkinson and Jane Mansbridge (eds.), Deliberative Systems. Deliberative Democracy at the Large Scale, cup, Cambridge, 2012: 72-94.

Bohman, James. Survey Article: The Coming of Age of Deliberative Democracy. The Journal of Political Philosophy 6 (4) (1998): 400-425.

Bonneau, Chris W. \& Gann Hall, Melinda. In Defense of Judicial Elections. Routledge, New York, 2009.

Boswell, John, Carolyn M. Hendriks \& Selen A. Ercan. Message received? Examining transmission in Deliberative Systems. Critical Policy Studies 10 (3), 2016: 263-283.

Button, Mark \& David Michael Ryfe. What can we Learn from the Practice of Deliberative Democracy?. In John Gastil \& Petter Levine (eds.). The Deliberative Democracy Handbook. Strategies for Effective Civic Engagement in the 21 st Century, Jossey-Bass, San Francisco: 2005: 20-33. 
Calvert, Aubin \& Mark E. Warren. Deliberative Democracy and Framing Effects: Why Frames are a Problem and How Deiberative MIni-Publics MIight Overcome Them. In Grönlund, Kimmo, André Bächtiger \& Setälä, Maija (eds.). Deliberative Mini-Publics. Involving Citizens in the Democratic Process, ECPR Press, Colchester, 2014: 203-223.

Chambers, Simone. Deliberation and Mass Democracy. In John Parkinson \& Jane Mansbridge (eds.), Deliberative Systems. Deliberative Democracy at the Large Scale, CuP, Cambridge, 2012: 53-71.

Chambers, Simone. Deliberative Democratic Theory. Annual Review of Political Science 6, 2003: 307-326.

Cohen, Joshua. Deliberation and Democratic Legitimacy. In James Bohman \& William Rehg (eds.). Deliberative Democracy, The mIT Press, Cambridge, Massachusets \& London.1998, 67-92.

Couso, Javier A. The Politics of Judicial Review in Chile in the Era of Domestic Transition, 1990-2002. In Siri Gloppen, Roberto Gargarella \& Elin Skaar (eds.). Democratization and the Judiciary. The Accoountability Function of Courts in New Democracies, Frank Cass, New York, 2005, 70-91.

Dahl, Robert. Democracy and its Critics. yup, New Haven \& London, 1989.

Delli Carpini, Michael X., Fay Lomax Cook \& R. Lawrence Jakobs . Public Deliberations, Discursive Participation and Citizen Engagement: A Review of the Empirical Literature. Annual Review of Political Science 7 (1), 2004: 315-344.

Donnelly, Tom. Making Popular Constitutionalism Work. Wisconsin Law Review 2012: 159-194.

Elster, Jon. Introduction. In Jon Elster, (ed.) Deliberative Democracy. cup, Cambridge, 1998, 1-18.

Fishrin, James S. The Voice of the People. Public Opinion and Democracy. Yup, New Haven, 1997.

Fishrin, James S. \& Robert C. Luskin. The Quest for Deliberative Democracy. In Michael Saward (ed.). Democratic Innovation: Deliberation, Representation and Association Routledge, London, 2000, 17-28.

Fishrin, James \& Cynthia Farrar. Deliberative Polling. From Experiment to Community Resource. In John Gastil \& Peter Levine (eds.). The Deliberative Democracy Handbook. Strategies for Effective Civic Engagement in the 21st Century, Jossey - Bass, San Francisco, 2005, 68-79.

Friedman, Barry. Mediated Popular Constitutionalism. Michigan Law Review 101 (8), 2003: 2596-2636.

Fung, Archon. Survey Article: Recipes for Public Spheres: Eight Institutional Design Choices and Their Consequences. The Journal of Political Philosophy 11 (3), 203: 338-367.

Gardbaum, STEPhen. Reassessing the new Commonwealth model of constitutionalism. ICON 8, 2010: 167-206. 
Gardbaum, Stephen. The New Commonwealth Model of Constitutionalism. Theory and Practice. cup, Cambridge, 2013.

Gargarella, Roberto. El nuevo constitutionalismo dialógico, frente al sistema de pesos y contrapesos. Revista Argentina de Teoría Jurídica 14 (2), 2013: 356-362.

Gargarella, Roberto. La justicia frente al gobierno. Sobre el carácter contramayoritario del poder judicial. Ariel, Barcelona, 1996.

Goodin, Robert E. \& John S. Dryzek. Deliberative Impacts: The Macro-Political Uptake of Mini-Publics. Politics \& Society 34 2, 2006: 219-244.

Gosh, ERIC. Deliberative Democracy and the Countermajoritarian Difficulty: Considering Constitutional Juries. oJLS 30 (2), 2010: 327-359.

Gutmann, Amy \& Dennis Thompson. Democracy and Disagreement. The Belknap Press of Hup, Cambridge, Massachusetts \& London ,1996.

Habermas, Jürgen. Between Facts and Norms: Contributions to a Discourse Theory of Law and Democracy. The mit Press, Cambridge, Massachusetts, 1996.

Habermas, JÜrgen. Justification and Application. Remarks on Discourse Ethics. The MIT Press, Massachussets \& London, 1993.

Hanssen, Andrew F. The Political Economy of Judicial Selection: Theory and Evidence. Kansas Journal of Law \& Public Policy 9 (3), 1999: 413-424.

Hendriks, Carolyn M. Consensus Conferences and Planning Cells. Lay Citizen Deliberations. In John Gastil \& Peter Levine (eds.). The Deliberative Democracy Handbook. Strategies for Effective Civic Engagement in the 21st Century. Jossey Bass, San Francisco, 2005: 80-110

Hiebert L., Janet. Parliamentary Bills of Rights: An Alternative Model?. The Modern Law Review 69 (1), 2006: 7-28.

Hogg, Peter W. \& Allison A. Bushell. El Diálogo de la Carta Entre Tribunales y las Legislaturas. Revista Argentina de Teoría Juridica 14 (2), (2013).

Kant, Immanuel. Critique of Pure Reason. Hacket Publishing, Indianapolis \& Cambridge, 1996.

Kant, Immanuel. Toward Perpetual Peace. In Pauline Kleingeld ed.). Toward Perpetual Peace and Other Writings on Politics, Peace, and History. Yup, New Haven \& London 2006, 67-109.

Knowles, Helen J. \& Julianne A. Toia. Defining 'Popular Constitutionalism: The Kramer versus Kramer Problem. Southern University Law Review 42 (1), 2014: 31-59.

Kramer, LARry. “The Interest of the Man": James Madison, Popular Constitutionalism, and the Theory of Deliberative Democracy." Valparaiso Law Review 41 (2), 2007: 697-754.

Kramer, Larry. The People Themselves. Popular Constitutionalism and Judicial Review. oup, Oxford, 2004a. 
Larmore, Charles. A Critique of Philip Pettit's Republicanism. Philosophical Issues, 2001: 229-243.

Lorenzetti, Ricardo. Las Audiencias Públicas y la Corte Suprema. Revista Argentina de Teoría Política 14 (2), 2013.

Lovett, Frank. “Republicanism.” Standford Encyclopedia of Philosophy. 1011 2014, http:// plato.stanford.edu/cgi-bin/encyclopedia/archinfo.cgi?entry=republicanism.

Madison, James. Who Are the Best Keepers of the People's Liberties?. In Ralph Ketcham (ed.), Selected Writings of James Madison. Hackett Publishing Company, Indianapolis/ Cambridge, 2006, 227-229.

Manin, Bernard. On Legitimacy and Political Deliberation. Political Theory 15 (3), 1987: 338-368.

Manin, Bernard. The Principles of Representative Government. cup, Cambridge, 1997.

Mansbridge, JAne et al. A systemic approach to deliberative democracy. In John Parkinson \& Jane Mansbridge (eds.). Deliberative systems: deliberative democracy at the large scale. Theories of Institutional Design, cup, Cambridge, 2012, 1-26.

Mansbridge, Jane et al. The Place of Self-Interest and the Role of Power in Deliberative Democracy. The Journal of Political Philosophy 18 (1), 2010: 64-100.

Marcilla, Gema. Balancing as a Guide to Legislative Reasoning. Legisprudence 4 (1), 2010: 93-104.

Marmor, Andrei. The Language of Law. oup, Oxford, 2014.

Martí, José Luis. La república deliberativa. Marcial Pons, Madrid, 2006.

McCormick, John. Machiavellian Democracy. cup, Cambridge, 2011.

Miller, David. Deliberative Democracy and Social Choice. Political Studies 40 (1), 1992: 54-67.

Oliver-LALANA, DANIEL. ¿Le importa a alguien que los legisladores razonen? Sobre el análisis y el control del debate parlamentario de las leyes. Revista da Faculdade de Direito da Universidade de Lisboa 57 (2), 2016: 5-37.

Oliver-Lalana, Daniel. Foreword: Towards a Theory of Legislative Argument. Legisprudence 4 (1), 2010: 3-12.

Ovejero Lucas, Félix. La libertad inhóspita. Modelos humanos y democracia liberal. Paidós, Barcelona, 2002.

Parkinson, John. Deliberating in the Real World. oup, Oxford, 2006.

Pettit, Philip. On the People's Terms: A reply to five critiques. Critical Review of International Social and Political Philosophy (CRISPP) 18 (6), 2015: 687-696.

Pettit, Philip. On the People's Terms. A Republican Theory and Model of Democracy. cup, Cambridge, 2012. 
Pettit, Philip. Republicanism. A Theory of Freedom and Government. Clarendon Press, Oxford 1997.

Pintore, Anna. Democrazia e diritti. Sette studi analitici. Edizioni ets, Pisa, 2010.

Pitkin, Hanna. The Concept of Representation. University of California Press, Berkeley, 1967.

Post, Robert \& Reva Siegel. Democratic Constitutionalism. In Jack Balkin \& Reva Siegel (eds.). The Constitution in 2020. oup, Oxford, 2009, 25-34.

Pozen, David. Judicial Elections as Popular Constitutionalism. Columbia Law Review 110, $20102047-2134$.

Rehg, William. Translator's Introduction. In Jürgen Habermas, Between Facts and Norms. Contributions to a Discourse Theory of Law and Democracy, The мIт Press, Cambridge, Massachusetts, 1996, ix-xliii

Rodríguez Garavito, César. El Activismo Dialógico y el Impacto de los Fallos Sobre Derechos Sociales. Revista Argentina de Teoría Jurídica 14 (2), 2013: 211-244.

Ryan, Matthew \& Graham Smith. "Defining Mini-publics". In Kimmo Grönlund, André Bächtiger \& Maija Setälä (eds.). Deliberative mini-publics. Involving citizens in the democratic process, ECPR Press, Colchester, 2014, 9-26

Sanders, Lynn. Poll Envy: An Assessment of Deliberative Polling. The Good Society 9 , (1), 1999: 9-14.

SCHÄFER, ANDREAS. Deliberation in representative institutions: an analytical framework for a systemic approach. Australian Journal of Political Science, 2017: 1-17.

Schkade, David, Cass R. Sunstein \& Reid Hastie. When Deliberation Produces Extremism. Critical Review 2010: 227-252.

Schlink, Bernhard. Proportionality in Constitutional Law: Why everywhere but here. Duke Journal of Comparative \& International Law 22 (2012): 291-302.

Schmidt, Christopher. The Tea Party and the Constitution. 2011. The Tea Party and the Constitution. Available at: http://scholarship.kentlaw.iit.edu/fac_schol/546.

Schwartzberg, Melissa. Should Progressive Constitutionalism Embrace Popular Constitutionalism?, Ohio State Law Journal 72 (6), 2011, 1295-1316.

Sebastián, Linares. Justicia dialógica interinstitucional: de lege ferenda y de lege lata. Revista Argentina de Teoría Jurídica 14 (2), 2013.

Sieckmann, Jan. Legislative Argumentation and Democratic Legitimation. Legisprudence 4 (1), 2010: 69-91.

Skinner, Quentin. A Third Concept of Liberty. Proceedings of the British Academy, 2002: 237-268.

Skinner, Quentin. Hobbes and Republican Liberty. cup, Cambridge, 2008.

Skinner, Quentin. Liberty before Liberalism. cup, Cambridge, 1998. 
Sunstein, Cass. The Law of Group Polarization. The Journal of Political Philosophy 10 (2), 2002: 175-195.

Sydney, Algernon. Discourses Concerning Government. Edited by Thomas G. West, Liberty Fund, Indianapolis, 1698.

Tschentscher, Axel, André Bächtiger, Jürg Steiner \& Marco Steenbergen. Deliberation in Parliaments. Research Objectives and Prelminary Results of the Bern Center for Interdisciplinary Deliberation Studies (BIDS). Legisprudence 4 (1), 2010: 13-34.

Tushnet, Mark. Non-Judicial Review. Harvard Journal on Legislation 40 (2003): 453-492.

Tushnet, Mark. Taking the Constitution Away from the Courts. Pup, Princeton, 1999.

Urbinati, Nadia. Representation as Advocacy. Political Theory 28 (6), 2000: 758-786.

Waldron, Jeremy. Political Political Theory. hup, Cambridge, Massachusetts: 2016.

WaLdRon, JeREmy. Representative Lawmaking. Boston University Law Review 89 (2009): 335-355.

Waldron, Jeremy. The Core of the Case Against Judicial Review. The Yale Law Journal, 115 (2006): 1346-1406.

Waldron, Jeremy. The Dignity of Legislation. cup, Cambridge, 1999.

Wintgens, LuC J. Legisprudence as a New Theory of Legislation. Ratio Juris 19 (1), 2006: $1-25$.

Zietlow, Rebecca E. Popular Originalism? The Tea Party Movement and Constitutional Theory. Florida Law Review 64 (2), 2012: 483-512. 